University of Nebraska - Lincoln

DigitalCommons@University of Nebraska - Lincoln

Faculty Publications, Department of History

History, Department of

2010

Getting Out of a Rut: Decolonizing Western Women's History

Margaret D. Jacobs

University of Nebraska - Lincoln, mjacobs3@unl.edu

Follow this and additional works at: https://digitalcommons.unl.edu/historyfacpub

Part of the History Commons

Jacobs, Margaret D., "Getting Out of a Rut: Decolonizing Western Women's History" (2010). Faculty Publications, Department of History. 110.

https://digitalcommons.unl.edu/historyfacpub/110

This Article is brought to you for free and open access by the History, Department of at DigitalCommons@University of Nebraska - Lincoln. It has been accepted for inclusion in Faculty Publications, Department of History by an authorized administrator of DigitalCommons@University of Nebraska - Lincoln. 


\section{Getting Out of a Rut: Decolonizing Western Women's History}

\section{MARGARET D. JACOBS}

The author teaches in the history department at the University of Nebraska, Lincoln.

For over three decades, western women's historians have been working not just to challenge male biases within western history scholarship but also to create a more multicultural inclusive narrative. Paradoxically, however, the overarching narrative of western women's history continues to sideline women of color and to advance a triumphalist interpretation of white women in the West. This essay argues that a multicultural approach has not provided an adequate framework for understanding women and gender in the American West. Instead, western women historians must "decolonize" our narrative and our field through seriously considering the West as a colonial site. To do so, we must employ the tools and theories that scholars of gender and colonialism worldwide have developed to analyze other comparable colonial contexts and projects.

It's been over thirty years since Joan Jensen and Darlis Miller critiqued popular accounts of western women's history, as represented by Dee Brown's The Gentle Tamers, and provided an important agenda for future research. ${ }^{1}$ Since that time many western women's historians have produced important scholarship on women of color in the West and analyzed the faultlines of race and class, as well as gender, in the West. Following Jensen and Miller, many scholars have advanced a multicultural approach that attempts to be inclusive of all women in the West and have penned powerful internal critiques of our collective endeavor. Even to list all the books and articles produced by these historians, let alone do justice to their analyses, would quickly consume my word limit.

Yet the shelves of western women's history in bookstores (if such a topic is offered at all) are still filled with titles such as Stalwart Women: Frontier Stories of Indomitable Spirit (1999); Wild West Women: Travellers, Adventurers and Rebels (2000); Into a New Country:

1. Joan M. Jensen and Darlis A. Miller, "The Gentle Tamers Revisited: New Approaches to the History of Women in the American West," Pacific Historical Review, 49 (1980), 173-213.

Pacific Historical Review, Vol. 79, No. 4, pages 585-604. ISSN 0030-8684

(c) 2010 by the Regents of the University of California. All rights reserved.

Please direct all requests for permission to photocopy or reproduce article content through the University of California Press's Rights and Permissions website, at http://www.ucpressjournals. com/reprintinfo.asp DOI: phr.2010.79.4.585. 
Eight Remarkable Women of the West (2000); and Pioneer Mothers of the West, or, Daring and Heroic Deeds of American Women: Comprising Thrilling Examples of Courage, Fortitude, Devotedness, and Self-Sacrifice (2001). Moreover, when I teach a class on western women's history, most students expect the class to dwell on white pioneer women on the frontier. Many are disappointed when we "go off on tangents" to discuss "side issues" such as the experiences and perspectives of American Indian, Mexican, or Asian women. An unspoken assumption exists among most of my students, if not the majority of the U.S. public, that the story of women in the West is a narrative of white women's trials and triumphs on "the frontier." It's easy to feel frustrated that thirty years of scholarship on western women's history has not made much of a dent in popular images of the West.

I might have easily dismissed this phenomenon as a symptom of the ongoing tensions between academic and popular histories were it not for a comprehensive unpublished bibliography of western women's history that I read in the fall of 2009. The bibliography shows that the large majority of publications in the field are biographies, autobiographies, and studies of white women in the West, most of which seem to make little attempt to analyze whiteness, race, or class critically. While some scholars continue to produce multicultural studies, the accrued overarching narrative of western women's history still sidelines women of color and advances a triumphalist interpretation of white women's presence in the West. If this narrative could be visualized, the image that comes to mind is a Conestoga wagon lumbering along in a well-traveled trail-a rut actually. A sunbonneted Madonna of the Prairie holds the reins of the oxen. As she drives the wagon, she genially allows new stories to be strapped to the side and piled on top. But these stories perch precariously on the wagon; they don't really fit. They can be easily jettisoned if the going gets rough, and if they happen to topple off on their own, the wagon driver doesn't really miss them as she continues on her path.

In this essay, I contemplate why-after more than thirty years and so much robust scholarship-we seem to be stuck in a rut. I contend that, however necessary a corrective it may have been at one time, a multicultural approach to western women's history has not provided an adequate framework for understanding women and gender in the American West. Ultimately, I argue, this is because the master narrative of western women's history is a colonial 
account that serves to justify and buttress U.S. colonial aims in the region. In this essay, I suggest that we must "decolonize" our narrative and our field through seriously considering the West as a colonial site. To do so, we must employ the tools and theories that scholars of gender and colonialism worldwide have developed to analyze other comparable colonial contexts and projects.

\section{Narrative and history}

Historians often work in isolation on topics that appear to non-historians to be obscure, narrow, or esoteric. Over time, however, as we labor in our individual ways, our scholarship accrues so as to create-either formally or informally-a narrative about the past. This narrative can take on the character of a collective body of knowledge, an epistemological framework. As Emma Pérez, a Chicana historian, observed: "If history is the way in which people understand themselves through a collective, common past where events are chronicled and heroes are constructed, then historical consciousness is the system of thought that leads to a normative understanding of past events." 2

I imagine these "normative understandings" in much the same way that I think of gender. Through thousands of daily actions, performances, interactions, and representations, we create norms about what it means to be male and female. Similarly, through our myriad pieces of scholarship, building on the work of others, we create historical norms, so to speak, by which we attempt to know the past. Through stringing historical events together, telling stories about past actors, and demonstrating patterns, we historians bring order to the past. Such narratives help us to look at the past not as a jumble of unconnected events and people, but as a coherent story. Like gender orders, historical narratives help us make sense of the society we occupy.

But, like gender orders, historical narratives also can be immensely constricting. They can serve to create social and national identities, often excluding events and groups of people that don't fit neatly into the narrative. Western women's historians have been familiar with and critical of the master narrative of western history for the ways in which it has excluded, marginalized, and

2. Emma Pérez, The Decolonial Imaginary: Writing Chicanas into History (Bloomington, Ind., 1999), 7. 
silenced women. In 1983, for example, Susan Armitage characterized this narrative as "Hisland," "a mythic place perpetuated in western history texts and survey courses," where "'a cast of heroic [male] characters engage in dramatic combat, sometimes with nature, sometimes with each other." Women are almost entirely absent from the scene, except perhaps as "hazy supporting figures far in the background, stoically oppressed or angelically supportive, and certainly voiceless and passive." ${ }^{3}$ Thus, just as feminists have contested gender orders throughout history and across the globe, western women's historians have contested the old master narrative of western history.

\section{Internal critiques of western women's history}

Yet over time western women's historians have created narratives that have been equally limiting and exclusive. The earliest western women's history narrative sought to recover white women's experiences, primarily on the Overland Trail or as settlers in the nineteenth century. This mirrored and built on dominant trends in 1970s women's history scholarship that focused prominently on white middle-class women's experiences in the nineteenth century. Driven by interest in the so-called cult of domesticity or true womanhood, early works on western women's history concentrated on how white women's experience of migration to the West differed from men's, whether white women voluntarily agreed to migrate, and whether they maintained gender ideals in transit and in their new homes. ${ }^{4}$

From its inception, this narrative did not go uncontested. In their well-known and influential 1980 essay, "The Gentle Tamers Revisited," Jensen and Miller implicitly critiqued the dominant narrative of western women's history at the time, which they found encapsulated in Brown's The Gentle Tamers. In their overview of the most common images of western women, Jensen and Miller identified "four major categories: gentle tamers, sunbonneted helpmates,

3. Elizabeth Jameson and Susan Armitage, "Editors' Introduction," in Jameson and Armitage, eds., Writing the Range: Race, Class, and Culture in the Women's West (Norman, Okla., 1997), 3.

4. John Mack Faragher, Women and Men on the Overland Trail (New Haven, Conn., 1979); Lillian Schlissel, Women's Diaries of the Westward Journey (New York, 1982); Julie Roy Jeffrey, Frontier Women: Civilizing the West? 1840-1880 (New York, 1979). 
hell-raisers, and bad women." They wrote that "a newer, ethnically broader and more varied image of women in the West is today challenging that older view. This view rests on a multicultural approach which calls for an evaluation of the experiences of all ethnic groups of women within a historical framework incorporating women's history into western history." ${ }^{6}$ Undoubtedly influenced by trends in women's history as well as by women of color's critique of the feminist movement, Jensen and Miller proposed "a new multicultural framework as a focus for western women." Rereading their essay today, thirty years later, the depth of their research and clarity of vision are still striking. Jensen and Miller provided an enduring and worthy map for the field.

Twelve years later, in 1992, a number of other western women's historians published important essays to re-review the field. Virginia Scharff analyzed the extent to which new scholarship on ethnic racial women in the West had transformed western women's history. Alluding to the tensions that had developed as a result of a more multicultural approach, she pointed out that "scholars of color today are debating the merits of attempting to integrate their work into a politically suspect field, or building a separate body of knowledge." Revealing her own personal effort to include racial ethnic women in western women's history, Scharff wrote, "I have moved away from seeking a narrative line for women's history, to trying to learn about, describe, and compare various women's experiences in different times and places." 9

Karen Anderson seized upon Jensen and Miller's suggestion that "what is most needed is a picture of how women fit into the economic structure in the West through their labor." Examining class relations, Anderson promoted the "analytical potential of the study of women's work in the west" and asserted that "realizing that potential requires that we recommit to doing history from the "bottom' up and that we move beyond 'fear of theory." 10

5. Jensen and Miller, "The Gentle Tamers Revisited," 178-179.

6. Ibid., 174 .

7. Ibid., 185 .

8. Virginia Scharff, "Else Surely We Shall All Hang Separately': The Politics of Western Women's History," Pacific Historical Review, 61 (1992), 543.

9. Ibid., 544.

10. Karen Anderson, "Work, Gender, and Power in the American West," Pacific Historical Review, 61 (1992), 481, 499. 
In the most vehement internal critique of the field, Antonia Castañeda, in her essay "Women of Color and the Rewriting of Western History: The Discourse, Politics, and Decolonization of History," critiqued the multicultural approach to the history of women in the West. To Castañeda, "Euro-American individuals or groups, both male and female, remain the true subject of multicultural studies," and "theoretical approaches that incorporate the historical realities of people of color, and their own interpretation of their realities, are still wanting." ${ }^{11}$ Further, Castañeda castigated a multicultural framework for failing to "analyze the relations of power among women of different races, classes, or cultures in the West." She asserted that "[m]ulticultural works about women written during the . . 1980s tend to emphasize harmonious, cooperative, mutually supportive relations between women of color and Anglo women in the American West. .. . [T] heir accounts are remarkably free of intercultural conflict in a land bloodied by three centuries of war and conquest." Castañeda pointed out that, "Ironically, by emphasizing the benign, conflict-free relationships between white women and women of color in the American West, multicultural studies reaffirm the notion that white women are the 'gentle tamers."'12

Another decade on, building on Castañeda's critique, Albert Hurtado issued a more understated plea for considering the role of colonialism in his essay, "Settler Women and Frontier Women: The Unsettling Past of Western Women's History." His brief but pointed article discusses the role of women's biological, household, and social reproductive labor in settler colonial projects. Originally an American Indian historian who gradually saw the necessity of looking at women and gender, Hurtado pointed out that "settler women's lives were a routine part of the day-to-day transformation of the American West from Indian country to public domain and to private property, and the establishment of political, economic, and social hegemony. ... The activities of settler women (whatever their ethnic background) were not value neutral. However homely and restricted their lives may seem in [the early twenty-first century], the presence of settler women in the West was not benign. Directly and indirectly they contributed to the dispossession of

11. Antonia Castañeda, "Women of Color and the Rewriting of Western History: The Discourse, Politics, and Decolonization of History," in ibid., 515.

12. Ibid., 519, 520, 521. 
American Indians and the transformation of Indian country into industrial and agricultural landscapes." ${ }^{\text {13 }}$

Thus in 1992 and again in 2001 western women's historians were challenging future historians to take not only race and ethnicity into consideration in western women's history but also to analyze class and colonialism seriously. As a result of these diverse and forceful critiques from ten to twenty years ago, we would expect that western women's history would be a dynamic and clamorous field today. Yet, in conducting research for this essay, I found instead that the field seems to be stuck in a rut of sorts. Many western women's historians have continued to focus uncritically on white women. Many others have readily embraced a multicultural approach but have not come to grips with the challenges laid down by Anderson, Castañeda, and Hurtado to address issues of power, whether through class, race, or colonial relations. The "master" narrative of western women's history looks much as it did in the 1980s.

\section{Are all the women still white?}

For some time, I've had a feeling that the enterprise of western women's history was still primarily centered around white women, but a feeling is not sufficient when you are a historian. So I decided to test my instincts by analyzing a recent comprehensive bibliography of western women's history scholarship from the last ten years compiled by Jameson Sweet, a graduate student at Montana State University. ${ }^{14}$ My quantitative study of Sweet's bibliography confirmed some of my notions but surprised me in other ways. First, I found that the largest numbers of publications (147) were within a category of biography, autobiography, and memoir (88 articles, 31 monographs, 25 edited collections, and three dissertations). Of these 147 publications, 116 appear to be about white women. The second-largest category for scholarship (100 publications) concerned politics and suffrage (74 articles, 11 monographs, an edited collection, and 14 dissertations). Of these 100, 92 appeared to

13. Albert Hurtado, "Settler Women and Frontier Women: The Unsettling Past of Western Women's History." Frontiers: A Journal of Women Studies, 22, No. 3 (2001), 3.

14. Jameson Sweet, "History of Women in the American West: A Bibliography, 1999-2009," unpublished manuscript in author's possession. In studying Jameson Sweet's bibliography, I have added a few articles and books and moved some entries to different categories. 
be about white women. Interestingly, in this second category, 37 of the entries were still biographical. The third-largest category (80), which surprised me, covered Native American women (53 articles, 17 monographs, 7 edited collections, and 3 dissertations). This category too included 24 biographical articles. I had expected to find more on homesteading, but this field had a similar number of entries as the fields of business and labor history, legal and criminal history, and community and urban history. Nevertheless, 27 of the entries in biography and autobiography concerned pioneering and homesteading women.

What are the implications of this brief and admittedly unscientific quantitative study? First, it's important to consider the predominance of biographical studies and autobiographies. As Karen Leong finds in her essay in this forum, biographical studies of nonwhite women have released a "plethora of unbound voices" that have reshaped the discourse of the western historical experience. But the majority of biographical and autobiographical work on western women remains fixated on white women, and we need to ask how this contributes to a colonial narrative. As Susan Armitage has commented, "the impulse to recover and restore overlooked women remains a fundamental and worthy part of all feminist scholarship," but biographers usually "add people to an existing historical narrative rather than trying to challenge that narrative head-on." ${ }^{15}$ Moreover, the attention to individual women's stories does not lend itself to analyzing patterns and power structures.

Second, a focus on politics and suffrage, mostly among white women, implies that a central story of women in the West concerns white women's lack of political rights and their struggles to gain political power and authority. Studies of politics and suffrage do address issues of power but focus primarily-and almost solely-on gender among white women, often ignoring other circuits of power, including racial inequalities, class dynamics, and colonial relations. In short, as this bibliography reveals, much of recent western women's history scholarship has engaged in a kind of women's history recovery project that is much more in line with 1970s historical enterprises than with current scholarship in U.S. women's history and western history as a whole.

15. Susan Armitage "Western Women's Biographies," Western American Literature, 41, No. 1 (Spring 2006), 72. 
This is not to say that there is no place for the continued study of white women in the American West. I would challenge such scholarship, however, to consider the identities of white, middleclass women in the West not just as gendered beings but as racialized and national subjects who were part of a settler colonial project and formed their identities in relation and opposition to indigenous people, Mexican settlers, and immigrant populations in the West. ${ }^{16}$

Sweet's bibliography does reveal quite a bit of scholarship on Native American women, which, on the surface, represents an important intervention into a narrative centered on white women's individual exploits, suffrage and politics, and pioneering and homesteading. Digging a little deeper, however, shows that even scholarship on Native Americans does not necessarily challenge the master narrative. Sacagawea remains an object of popular and scholarly inquiry, with five out of twenty-four biographical studies devoted to her. These works tend to reproduce old debates about Sacagawea's origins and ultimate destiny and thus deflect attention away from questions of power and colonial relations. The significant number of biographies-while invaluable in recovering Native American women's experiences and perspectives-serve to individualize Native American history rather than showing important shared overall experiences. Other popular topics, including captivity of white women by Native Americans, Native American women's religious ceremonies, and Native American women artists, also tend to avoid larger structural questions of power.

Ultimately, while giving us a bird's eye view of the field of western women's history, Sweet's bibliography itself reflects and helps to construct a western women's history narrative. Its categoriessuch as African American women, Asian women, Latinas, and so on-treat historical subjects in isolation from one another. Its topical categories-such as agriculture and homesteading, business and labor, community and urban, environment, and marriage and domesticity-shape our sense of what is important. The fact that

16. Three books that analyze white women as racialized subjects (among other topics) include Linda Gordon, The Great Arizona Orphan Abduction (Cambridge, Mass., 1999); Katherine Benton-Cohen, Borderline Americans: Racial Division and Labor War in the Arizona Borderlands (Cambridge, Mass., 2009); and Peggy Pascoe's classic, Relations of Rescue: The Search for Female Moral Authority in the American West, 1874-1939 (New York, 1990). 
the bibliography includes no categories that capture the dynamic nature of western encounters-no categories on the borderlands, colonialism and colonization, or even cultural encounters-also serves to draw borders around the field, designating what's in and what's outside of its purview.

\section{Embracing the multicultural approach}

Certainly not all scholarship on western women's history of the last ten to twenty years has contributed to a triumphalist narrative of white women in the West. Many scholars have produced significant work on women of color in the West, and, taking internal critiques to heart, many western women's historians have sought to create a more inclusive narrative. ${ }^{17}$ Yet, while unarguably an important corrective and a step in the right direction, the multicultural approach has obscured certain power dynamics and inadvertently helped to shape and reinforce a colonial narrative of western women's history.

The multicultural approach, and its limitations, is exemplified in one of the few synthetic texts about western women's history, Harriet Sigerman's Land of Many Hands: Women in the American West. ${ }^{18}$ The book, written for young adults, is well written and incorporates much of the western women's history scholarship of the 1980s and early 1990s, yet, as I detail below, it ultimately contributes to a colonial narrative. The book opens in 1848, not from the vantage point of Mexican women, whose land had just been conquered by the United States, or from the perspective of Native American women, who had experienced colonization at the hands of many different Europeans and now faced a fresh onslaught from European Americans. Rather, in typical fashion, the book opens with the tale of a migrant European American couple and the travails of the white woman. After five pages on European American women, the book presents a paragraph on European and Asian immigrant women, lumped together, a paragraph on African American and Mexican women—of just six lines—and then a final

17. Jameson and Armitage, eds., Writing the Range (in which I published my first article), is a prime example of this approach.

18. Harriet Sigerman, Land of Many Hands: Women in the American West (New York, 1997). 
six-line paragraph on Native American women. Then it's back to white women for a few more pages.

To her credit, Sigerman did return at the end of the chapter to the "war against the first inhabitants of the West, Native Americans." Paying her respects to the "new western history of the late 1980s," she asserted, "When the wagon trains reached their destinations in the West, they did not enter a land devoid of people or settlement. Instead they encountered an array of highly developed Indian cultures that had lived throughout the West for thousands of years. But settlers' growing demands for the rich farming and mining lands of the West . . . led to savage violence against Native Americans." Thus, Sigerman wrote, "The course of westward migration is inextricably bound with this shameful history of government deceit, repression, and violence against American Indians." ${ }^{\text {19 }}$ For a young adult textbook, this is pretty strong stuff.

Yet, Sigerman did not quite know what to do with women within this framework. She wrote, "The westward movement was like a vast stage on which native peoples and settlers played out a dramatic struggle to survive and to carve out a hardy way of life on the land. In an often harsh and unyielding, but also bountiful land, western women did their part. . . . The dramatic story of westward expansion is also the story of women-Indian, Hispanic, white, African-American, European, and Asian-who helped to settle the West and shape the course of American history." ${ }^{20}$ A "shameful history" is transformed into a "dramatic story" in which all players are cast equally. A complicated history becomes yet again a triumphalist story.

This awkward shuttling between multiculturalism and triumphalism is continued throughout the rest of the book. The book begins with a substantive chapter on Native American women in the West and "early Hispanic settlement." Yet once Sigerman brings American settlers into the picture in chapter 2, the book reverts almost entirely to a colonial narrative. "The history of America, then, is the history of a nation on the move," the text asserts, "as settlers continually pushed the boundaries back to seek new land and opportunity." ${ }^{21}$ Gone is the "shameful history" and "savage

19. Ibid., 14.

20. Ibid., 15 .

21. Ibid., 43. 
violence" against Native Americans. Sigerman has made her obligatory disclaimer in the introduction and now can move on to the familiar and comforting narrative of "a nation on the move."

Briefly integrating blacks and Asian immigrants, Sigerman's book celebrates the multiculturalism of the West: "by the mid19 th century, the West was the most ethnically diverse region of the United States, a mosaic of inhabitants from across the globe." While it points out that this mosaic "was far from harmonious," and that "the history of Chinese and Japanese immigration, in particular, is a sorry tale of cruelty, prejudice, and intolerance," a multicultural narrative cannot really explain why such cruelty and prejudice existed. ${ }^{22}$ Thus, "the sorry tale" becomes an unfortunate and regrettable detour on the road to multicultural enlightenment rather than a key ingredient of a colonial strategy. Gradually nonwhite women nearly drop out of the narrative entirely. Chapters 3 through 7, detailing "Life on the Overland Trail," "Homemaking on the Frontier," "Making a Life on the Frontier," "Western Women at Work," and "Building New Communities," only include token non-white women.

Sigerman's book is illustrative of the limits of a multicultural approach to western women's history. Such an approach assembles women of various cultural backgrounds in the West in an ahistoricized, depoliticized space, as if they are gathering for a friendly quilting bee or tea party. In short, it leaches out all the structural inequities and unbalanced power relations that were inherent to such encounters. This is not to fault Sigerman. She was synthesizing the scholarship, and the scholarship did not provide the framework necessary to create a more complex analysis of western women's history.

So, thirty years after Jensen and Miller challenged western women's historians to create a more inclusive narrative of western women's history, and nearly twenty years after Castañeda extended the challenge to decolonize western women's history, why is it still the case that white women predominate? And that, when women of color are "included," a multicultural approach takes precedence?

I contend (with Castañeda and Hurtado) that it's not enough to "be inclusive" if our overarching narrative is a colonial narrative. A multicultural approach to the history of women and gender 
in the West can take the field only so far, especially if it does not examine power relationships between women of different races and classes within a colonial context. Jensen and Miller were surely cognizant of this when they concluded that "A multicultural approach need not eliminate class or politics from western women's history. Rather, it can insure that the problems of political power and the political dimensions of social history are not ignored."23

Nevertheless, when put into practice, the multicultural approach to western women's history has tended to minimize questions of power emanating from race, class, and colonial dynamics. In simply including women of color without truly engaging in an analysis of the power relations between women within different social locations in the West, and without understanding the West as a colonial site, these inclusions seem innocuous at best and patronizing at worst. Southern women's historians would not be taken seriously if they failed to look at white southern women's ideas about race and their interactions with African American slaves and freedpeople. Similarly, it's not really possible any longer for historians of the British Empire to write uncritically of women of the Raj without paying attention to colonialism. If western women's historians continue to write uncritically about white women or about relations between women in the West-if we stay in our rut-we risk making ourselves irrelevant to western history, U.S. history, and global history.

\section{Gender and colonialism in the West}

I propose that western women's historians need to engage in a new collective scholarly enterprise centered on gender and colonialism in the West. Such an endeavor first entails coming to grips with colonialism and creating a working definition of it within the context of the West. It then demands that we connect our scholarship with others worldwide who are working on gender and colonialism. Such moves, I believe, will both revitalize the field and lead to more compelling and truer histories of women and gender in the West.

Conventional training in U.S. history and western history as discrete fields-separate from world history-has not provided

23. Jensen and Miller, "The Gentle Tamers Revisited," 212. 
adequate tools for considering the West as a colonial site. A number of scholars have critiqued the field of American history in general for failing to sufficiently acknowledge and analyze American empire. Amy Kaplan has written that "Unites States continental expansion is often treated as an entirely separate phenomenon from European colonialism in the nineteenth century, rather than as an interrelated form of imperial expansion. The divorce between these two histories mirrors the American historiographical tradition of viewing empire as a twentieth-century aberration, rather than as part of an expansionist continuum." ${ }^{24}$ Note that even Kaplan could not bring herself to use the word colonialism or colonization in reference to U.S. "expansion." Ironically, only one of the twenty-four articles in her co-edited volume, Cultures of United States Imperialism, deals explicitly with the West! Kaplan had some pertinent critiques of western (women's) history, however, as she noted that the "most recent revision of the frontier [as a site of contacts, encounters, and collisions that produce new hybrid cultures] risks downplaying the imperial dimensions of power and violence that structure, underwrite, and are informed by cultural "interpenetrations." ${ }^{25} \mathrm{In}$ a more recent critique, Ann Laura Stoler, an anthropologist who specializes in Dutch colonialism in Indonesia, called for bringing postcolonial studies and North American history into conversation with one another. She wrote that "these fields share more points of comparative reflection than either field has recognized or allowed." 26

Calling for seeing the West as a colonial site, however, is not a simple matter. There are many contending conceptualizations of just what that might mean. Kaplan, for example, notes that the "field of Chicano studies has begun to redress the conceptual limits of the frontier, by displacing it with the site of 'the borderlands'... . The borderlands link the study of ethnicity and immigration inextricably to the study of international relations and empire. At these borders, foreign relations do not take place outside the boundaries of

24. Amy Kaplan, "Left Alone with America: The Absence of Empire in the Study of American Culture," in Amy Kaplan and Donald Pease, eds., Cultures of United States Imperialism (Durham, N.C., 1993), 17.

25. Ibid., 16.

26. Ann Laura Stoler, "Intimidations of Empire: Predicaments of the Tactile and Unseen," in Ann Laura Stoler, ed., Haunted by Empire: Geographies of Empire in North American History (Durham, N.C., 2006), 1. 
America, but instead constitute American nationality." ${ }^{27}$ Indeed, the study of borderlands has become a vibrant field. As Ben Johnson conceptualized it,

For nearly four centuries, the borderlands-the region on either side of the border that now divides the United States and Mexico-has witnessed multiple collisions, conquests, and accommodations among an array of native peoples and representatives of the Spanish Empire, Mexico, the Republic of Texas, and the United States. . . . Historians and scholars therefore should not assume that nations are the inevitable vessels of sovereignty, popular identity, or collective aspiration. From this perspective, the physical edges of countries and empires may reveal the most about the contingency of national histories and provide the best prospects for creating accounts of the past that cross borders freely. ${ }^{28}$

While evocative of the dynamism of cultural encounters and the fluidity of national borders, the concept of the borderlands-involving "multiple collisions, conquests, and accommodations"still seems to evade identifying the central process at work in the West, namely colonialism.

Some historians have embraced the concept of internal colonialism to describe power relations within the West. Most recently, Linda Gordon, following her award-winning The Great Arizona Orphan Abduction, has called for reviving this once-popular framework to understand the West. Curiously, Gordon's conception of internal colonialism revolves almost entirely around struggles between Anglos and Mexicans in the Southwest and has nothing to say about indigenous peoples. She wrote, for example, "As the original possessors and/or owners of much of the land annexed [by the United States] (notably in California, New Mexico, and Texas), they [Mexican Americans] were expropriated by legal as well as illegal means." ${ }^{29}$ In using the term to "delineate the position of Mexican Americans" in the West, Gordon was understanding internal colonialism as a "metaphor and an analytic abstraction." 30

27. Kaplan, "Left Alone with America," 16-17.

28. Benjamin Johnson, "Engendering Nation and Race in the Borderlands," Latin American Research Review, 37, No. 1 (2002), 259-260. See also Ramón Gutiérrez and Elliott Young, "Transnationalizing Borderlands History," Western Historical Quarterly, 41 (2010), 27-53.

29. Linda Gordon, "Internal Colonialism and Gender," in Stoler, ed., Haunted by Empire, 435.

30. Ibid., 428. 
Yet there was nothing metaphorical or abstract about the colonialism experienced by indigenous peoples in North America. Moreover, even if we were to apply the concept of internal colonialism to Native Americans in the West, it seems ahistorical to read the American nation back into the West centuries before the United States actually conquered and colonized the region. The West was not "internal" to the United States prior to the mid-nineteenth century. Furthermore, this concept mistakes the twentieth-century legacies and continuities of colonialism for "internal" colonialism.

Some of us may be wary of using the term "colonialism," pure and simple, to denote processes at work in the West because so many scholars of colonialism have identified themselves as "postcolonialists," and their formulations do not seem to quite fit in the context of the American West. As Richard King pointed out, "Unfortunately postcolonial studies has rapidly established a fairly stable canon, one anchored within select thinkers and texts, devoted to Europe and its former colonies, delimited by decolonization." He further argued that "postcolonial studies are Eurocentric, focusing almost exclusively on Europe and its former colonies . . . theorists have all but ignored American empire." ${ }^{31}$ Historians of the West may also find the inordinate attention paid to literature and discourse within postcolonial studies to be somewhat off-putting. ${ }^{32}$

So how should we understand colonialism in the American West? Instead of using the terms "borderlands," "internal colonialism," or, simply, "colonialism" to describe the process within the western context, I've become an intellectual devotee to the alternative models for the study of colonialism that have emerged among historians of settler colonialism, particularly from Australia and Canada. These models seem more relevant and applicable to the American West. Canadian scholars Daiva Stasiulis and Nira Yuval-Davis define settler colonialism as a type of imperialism that resulted not in overseas empires but in "societies in which Europeans have settled, where their descendants have [become and] remained politically dominant over indigenous peoples, and where

31. C. Richard King, "Introduction: Dislocating Postcoloniality, Relocating American Empire," in C. Richard King, ed., Postcolonial America (Urbana, Ill., 2000), 3.

32. In fact, most scholars who have grappled with the issue of the applicability of postcolonial studies to the United States are literary and cultural studies scholars as well as anthropologists. See, for example, the collection of essays in King, ed., Postcolonial America. 
a heterogeneous society has developed in class, ethnic and racial terms." 33

Australian scholar Patrick Wolfe's theoretical work on settler colonialism offers a powerful framework for studying the American West. Wolfe explained that the settler colony's "aim is the replacement of native society. . . [ [I]ts governing logic is one of elimination" rather than incorporation of indigenous peoples. ${ }^{34}$ In other primarily extractive colonies, the indigenous population served as laborers on plantations, in mines, on railroads, and in factories, but in settler colonies the state sought instead to effect the disappearance of indigenous people and thus extinguish their claims to land. Thus, settler colonies have rested on importing labor-often slaves or indentured workers. A settler colonial framework explains two major developments in the West-the dispossession of Indian peoples and the importation and immigration of laborers from Asia and Mexico-as two sides of the same process. The need for cheap, exploitable labor, however, often conflicted with the ultimate goal of settler colonialism: to establish a white dominion in the West.

A number of scholars have highlighted the crucial role that gender plays in settler colonial projects along the lines of what Hurtado dubbed "intimate frontiers." 35 Ann Laura Stoler's work has provided a theoretical scaffolding for addressing "how intimate domains—sex, sentiment, domestic arrangement, and child rearingfigure in the making of racial categories and in the management

33. Daiva Stasiulis and Nira Yuval-Davis, "Introduction: Beyond DichotomiesGender, Race, Ethnicity and Class in Settler Societies," in Daiva Stasiulis and Nira Yuval-Davis, eds., Unsettling Settler Societies: Articulations of Gender, Race, Ethnicity and Class (London, 1995), 3. For more on settler colonies, see the comparison of six such colonies in the Southern Hemisphere in Donald Denoon, Settler Capitalism: The Dynamics of Dependent Development in the Southern Hemisphere (Oxford, U.K., 1983).

34. Patrick Wolfe, "Logics of Elimination: Colonial Policies on Indigenous Peoples in Australia and the United States," text of public lecture delivered at University of Nebraska, Feb. 21, 1999 (Lincoln, Nebr., International Human Rights and Human Diversity Initiative, University of Nebraska Lincoln, College of Arts \& Sciences, 2000), 2. Patrick Wolfe has also published an important and extended article that made similar points. See Wolfe, "Land, Labor, and Difference: Elementary Structures of Race," American Historical Review, 106 (2001), 872. See also Julie Evans, Patricia Grimshaw, David Philips, and Shurlee Swain, Equal Subjects, Unequal Rights: Indigenous Peoples in British Settler Colonies, 1830-1910 (Manchester, U.K., 2003), and Lynette Russell, ed., Colonial Frontiers: Indigenous-European Encounters in Settler Societies (Manchester, U.K., 2001).

35. Albert Hurtado, Intimate Frontiers: Sex, Gender, and Culture in Old California (Albuquerque, 1999). 
of imperial rule." ${ }^{36}$ Stoler noted that "matters of the intimate are critical sites for the consolidation of colonial power, that management of those domains provides a strong pulse on how relations of empire are exercised, and that affairs of the intimate are strategic for empire-driven states." ${ }^{37}$ Stoler's influential concept recognizes that colonialism requires a comprehensive, all-encompassing intervention into the most intimate realms of society.

To Stoler's interest in intimacy, I would add a need to confront a related topic: reproduction. As Hurtado pointed out in his 2001 critique, the reproduction of the settler population and its social order-both projects connected with white women-is central to settler colonial projects. Conversely, the control of the physical and social reproduction of both indigenous peoples and immigrants in the West is also a key component of settler colonial aims. The centrality of reproduction to settler colonialism-and its link to "intimate frontiers"-makes gender a crucial analytical category in our studies of the West.

The adoption of a colonial framework would enable western women's historians to connect with scholars worldwide who are working on gender and colonialism, to contextualize western women's history within world history, and to engage in comparative historical projects. ${ }^{38}$ Although western historians try to avoid the "exceptionalist" trap, we often persist in seeing what appear to be western phenomena in the United States in isolation from other similar processes on other "frontiers" or, as I prefer to call them, "colonial sites." When we read only U.S. history or western U.S. history, we become inured to taken-for-granted narratives. When we read other historians who study women and gender in other colonial settings, especially settler colonies, we gain crucial new insights that may help us to reconceptualize our field.

I can speak from personal experience about how intellectually rewarding it can be to get outside our academic comfort zones. When I wrote my first book, during the heyday of the multicultural western women's history narrative, I was inspired by Peggy Pascoe's attempts to look at relations between women in the West, not just to

36. Ann Laura Stoler, “'Tense and Tender Ties': The Politics of Comparison in North American History and (Post) Colonial Studies," in Stoler, Haunted by Empire, 23.

37. Stoler, "Intimidations of Empire," 4.

38. In her 1992 essay, Castañeda similarly called for "historical studies on comparative frontiers that begin to examine frontier expansion within a global context of European colonization and development." See Castañeda, "Women of Color," 524-525. 
take a mosaic-like approach to western women's history. ${ }^{39}$ Yet, while I acknowledged power imbalances, tensions, and conflicts between white women and Pueblo Indians, I struggled to name the nature of the power relations I scrutinized. My understanding of these "engendered encounters" lacked a strong analytical framework. When I began to do research in Australia for my second book, I read the challenging work of Australian feminist scholars who were developing the concept of settler colonialism and attempting to understand gender within it. ${ }^{40}$ Suddenly, I saw familiar topics in western women's history with fresh eyes and asked new questions: How did white women's reform agendas compare in both the American West and Australia, and why did women in both nations support the draconian policy of separating indigenous children from their families? ${ }^{41}$

Of course, not all questions that western women's historians consider must or should fall within a framework of colonialism. Other topics compel, move, and inspire us to do historical detective work. Moreover, a colonial framework can sometimes undermine new approaches to understanding the histories of people of color on their own terms. Yet, a colonial framework need not continue to marginalize people of color. Much recent work on gender and

39. Pascoe, Relations of Rescue; Margaret Jacobs, Engendered Encounters: Feminism and Pueblo Cultures, 1879-1934 (Lincoln, Nebr., 1999).

40. For a sampling of such scholarship, see Patricia Grimshaw, Marilyn Lake, Ann McGrath, and Marian Quartly, Creating a Nation, 1788-1990 (Ringwood, Victoria, 1994); Ann Curthoys, "Colonialism, Nation, and Gender in Australian History," Gender and History, 5 (Summer 1993), 165-176; Marilyn Lake, "Feminism and the Gendered Politics of Antiracism, Australia 1927-1957: From Maternal Protectionism to Leftist Assimilationism," Australian Historical Studies, 29 (April 1998), 91-108; Alison Holland, "Wives and Mothers Like Ourselves? Exploring White Women's Intervention in the Politics of Race, 1920s-1940s," in ibid., 32 (Oct. 2001), 292-310; Anna Cole, Victoria Haskins, and Fiona Paisley, eds., Uncommon Ground: White Women in Aboriginal History (Canberra, 2005); Victoria Haskins, One Bright Spot (New York, 2005); Fiona Paisley, Loving Protection? Australian Feminism and Aboriginal Women's Rights, 1919-1939 (Carlton South, Victoria, 2000); Katherine Ellinghaus, Taking Assimilation to Heart: Marriages of White Women and Indigenous Men in the United States and Australia, 1887-1937 (Lincoln, Nebr., 2006). Canadian scholars have also been working on gender and colonialism. See Sarah Carter, The Importance of Being Monogamous: Marriage and Nation Building in Western Canada to 1915 (Edmonton, Alberta, 2008); Adele Perry, On the Edge of Empire: Gender, Race, and the Making of British Columbia, 1849-1871 (Toronto, 2001); Carol Williams, Race, Gender, and the Photographic Frontier in the Pacific Northwest (New York, 2003).

41. My second book is Margaret D. Jacobs, White Mother to a Dark Race: Settler Colonialism, Maternalism, and the Removal of Indigenous Children in the American West and Australia, 1880-1940 (Lincoln, Nebr., 2009). 
colonialism has made "the colonized" population central, drawing out the class and gender divisions within this often homogenized group and showing the complex and dynamic ways in which indigenous peoples and immigrants grappled with state policies, new economic relations, racial hierarchies, and clashing gender orders. ${ }^{42}$

\section{Decolonizing western women's history}

Ultimately, as western women's historians question old narratives and confront questions of colonialism, we are required to think about our own positions in relationship to our subject matter and to be clear about our purpose. As Castañeda argued in 1992, "The structures of colonialism are the historical legacy of the United States and, as such, inform the profession of history and the production of historical scholarship as much as they do any other human relationship and endeavor. If western history is to be decolonized, historians must be conscious of their power and ideology within the structures of colonialism, and conscious as well of the ways in which historical scholarship has helped to sustain and reproduce those structures. ${ }^{, 3}$ Thus, if we acknowledge the history of the West as a history of colonialism, what then is our responsibility as historians? What is our role in promoting decolonization ${ }^{34}$

Decolonizing western women's history demands that we seriously examine our own roles as historians in perpetuating or disrupting colonial narratives. It demands, too, that we stretch ourselves intellectually, take risks, and develop new alternative accounts of the past. This process will not be easy. There will be conflict and tension within our ranks as we talk about the legacies of colonialism-trauma, pain, distrust, anger, denial, guilt. There will undoubtedly be popular resistance as we challenge cherished narratives of western history. But the rewards will be great: intellectual revitalization of a field that has gotten itself stuck in a rut and, most importantly, honest engagement with issues that are not just part of the past, but still relevant today.

42. One example of this is Nancy Rose Hunt, A Colonial Lexicon: Of Birth Ritual, Medicalization, and Mobility in the Congo (Durham, N.C., 1999).

43. Castañeda, "Women of Color," 533.

44. Sherry Smith pondered these questions in her recent WHA presidential address and article, "Reconciliation and Restitution in the American West," Western Historical Quarterly, 41 (2010), 5-25. 